A Reconnaissance

\title{
Study of the Beach
}

Sands of Puerto Rico

GEOLOGICAL SURVEY BULLETIN 1042 - I

Prepared in cooperation with the Economic Development Administration of the Commonwealth of Puerto Rico

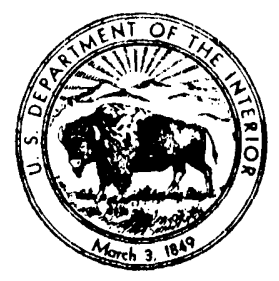





\section{ERRATUM}

Bulletin 1042-I. In table 3 the box heads of the fourth and fifth columus are reversed. 

A Reconnaissance

Study of the Beach

Sands of Puerto Rico

$B y$ ROBERT B. GUILLOU and JEWELL J. GLASS

CONTRIBUTIONS TO ECONOMIC GEOLOGY

GE O L G I A L S U R V E B U L L T I N 1042 - I

Prepared in cooperation with the

Economic Development Administration

of the Commonwealth of Puerto Rico

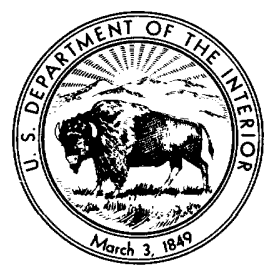




\title{
UNITED STATES DEPARTMENT OF THE INTERIOR
}

FRED A. SEATON, Secretary

\author{
GEOLOGICAL SURVEY
}

Thomas B. Nolan, Director 


\section{CONTENTS}

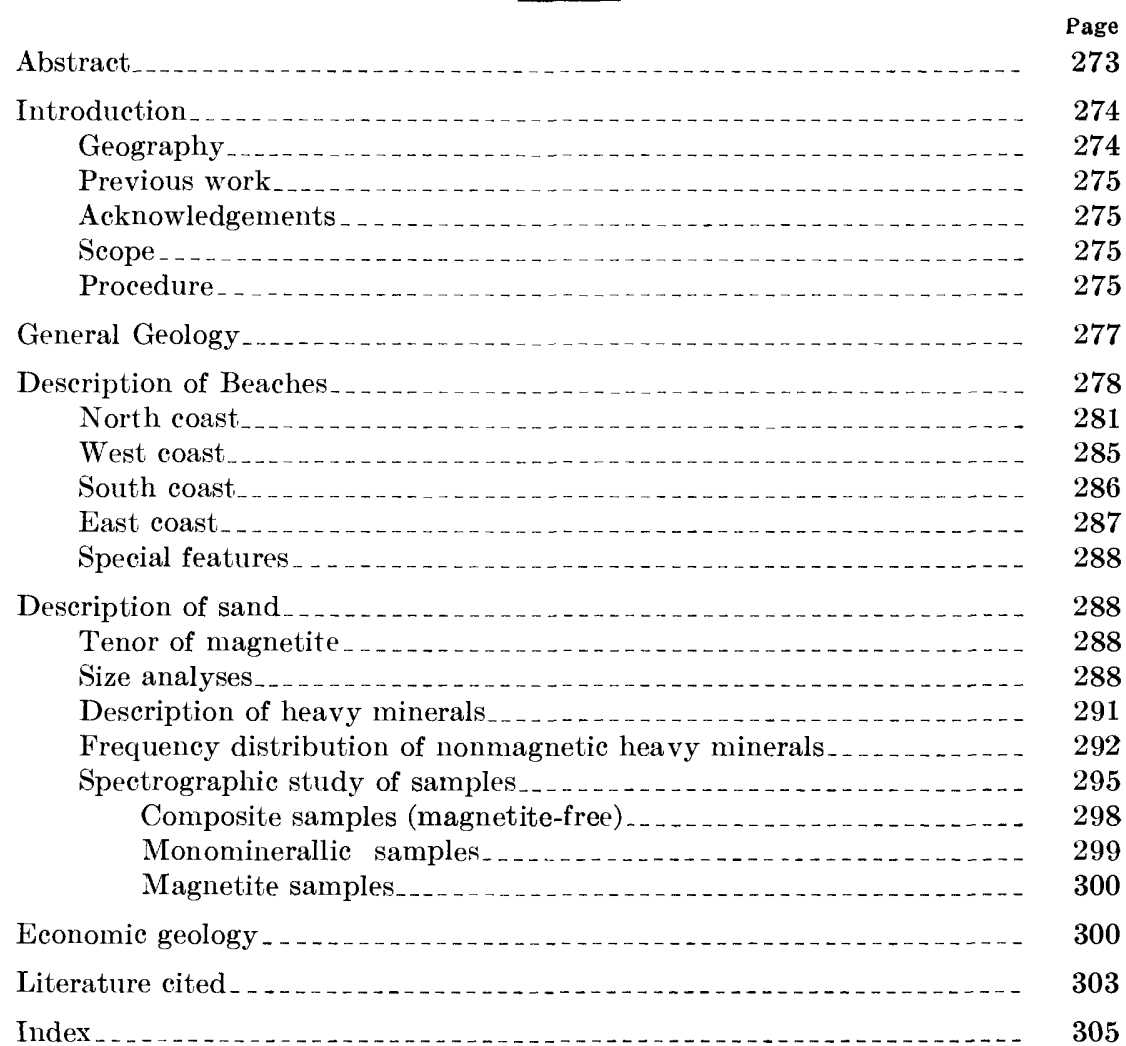




\section{ILLUSTRA'TIONS}

Plate 15. Generalized geologic map of Puerto Rico, showing shore features . . . . .

FigURE 31. View looking west from a point east of Palmas Altas_._. _. 283

32. Detail view of the banded magnetite-rich consolidated-sand beach rock on the north shore of Puerto Rico, west of Puerto Rico

33. View along the north shore of Puerto Rico, looking west from Palmas Altas.

34. Size analyses of representative Puerto Rico sands

\section{TABLE}

TABLE 1. Description of coasts and beaches of Puerto Rico

2. Tenor of magnetite in beach sands of Puerto Rico

3. Proportions of the sample fractions and frequency distribution of minerals in heavy nonmagnetic sample fraction in beach and dune sands

4. Percentages of major constituents in beach and dune sands ....

5. Semiquantitative spectrographic analysis for minor elements and quantitative analysis for niobium in 24 samples of beach sands

6. Semiquantitative spectrographic analysis for minor elements and quantitative spectrographic analysis for vanadium in 10 samples of magnetite from beach sands 


\title{
CONTRIBUTIONS TO ECONOMIC GEOLOGY
}

\section{A RECONNAISSANCE SURVEY OF THE BEACH SANDS OF PUERTO RICO}

\author{
By Robert B. Guillou and Jewell J. Glass
}

\begin{abstract}
ABS'TR AC' $\mathbf{Y}$
A reconnaissance survey of the beaches of Puerto Rico was made by the U. S. Geological Survey in cooperation with the Economic Development Administration of the Commonwealth of Puerto Rico to explore the sands for economic heavy minerals and to use the heavy minerals as guides in locating their sources in hardrock.

Narrow coastal sand dunes behind narrow beaches and rocky areas of consolidated sand are the normal shoreline features of the north coast of Puerto Rico from Luquillo to Camuy. Swampy areas and lagoons commonly occur between the coastal strip and the flat coastal plain. Magnetite and other heavy minerals are concentrated in beach and dune sand deposits near the mouths of the major rivers.

From Camuy to Aguadilla, the coast is characterized by cliffs 100-150 feet high, with narrow terraces near sea level. The content of heavy minerals in the sand of this area is low. Sandy beach predominates on the west from Aguadilla to Punta Guanajiba, south of Mayaguez, and concentrations of magnetite are found near the mouths of the larger rivers. The beach sands near Mayaguez contain minor amounts of chromite, in addition to magnetite.

The west and southwest shores, from Punta Guanajiba to Ponce, are composed of rocks, mangrove swamps, and beaches composed of shell fragments. Noncalcareous material comprises a low percentage of the beach sand, and heavy minerals are unimportant.

From Ponce eastward to the Río Grande de Patillas, the south coastal plain is composed of sediments of Quaternary age, except for an isolated area of older rocks at Central Aguirre; and the shoreline is a combination of mangrove swamps, beaches of sand and cobbles and rocky areas of consolidated sand and consolidated gravel. Heavy minerals are a major constituent of the beach sand in many places on the south coast and magnetite of ten constitutes more than 20 percent of the sand.

The east coast, from the Río Grande de Patillas to Naguabo, consists of outcropping volcanic and intrusive rocks of Cretaceous and early Tertiary age and sandy beaches. Rich concentrations of heavy minerals occur locally. In the northern portion of the east coast, rocks and swamps predominate but some calcareous beaches are present.
\end{abstract}


Recently consolidated sand of eolian and marine origin occurs on the north coast of the island as much as 50 feet above sea level. Elsewhere, consolidated sand and consolidated gravel are restricted to the littoral areas.

The most abundant heavy mineral in the beach sands of Puerto Rico is magnetite. It occurs on all shores of the island. Ilmenite is present, associated with the magnetite. Chromite, derived from serpentine, occurs in the sands of the west coast near Mayaguez. Sphene, although a minor constituent, is widely distributed in the beach sands. Zircon is rare.

Channel samples of the uppermost one to three feet of beach and dune sands were collected and the locations of the samples on the beach profile were noted. Conveniently sized samples were prepared and separated into three fractions: magnetic, heavy (sp. gr. $>2.80$ ) nonmagnetic, and a light (sp. gr. $<2.80$ ) nonmagnetic. Each fraction was weighed and studied microscopically. Samples of sand from selected localities were sieved and the percentages of magnetite in each fraction were determined. The data thus obtained are presented on graphs that show percentages, frequency distributions, and sizes of the mineral constituents.

Three-dimensional control in several areas on the north coast of Puerto Rico provide sufficient data for rough estimates of tonnages of the magnetite. At least 200,000 tons of magnetite, and possibly as much as 300,000 tons, is indicated to be present. Some of the lower flood plains of the larger rivers and the shallowwater offshore deposits of sand are suggested as areas for further study.

\section{INTRODUCTION}

\section{GEOGRAPHY}

Puerto Rico is an island of about 3500 square miles, roughly 35 miles from north to south and 100 miles from east to west, situated in the Caribbean island arc between Hispaniola and the Virgin Islands, at about latitudes $17^{\circ} 55^{\prime}$ to $18^{\circ} 30^{\prime} \mathrm{N}$. and longitudes $65^{\circ} 35^{\prime}$ to $67^{\circ} 15^{\prime} \mathrm{W}$. It has a tropical climate tempered by cooling northeast trade winds throughout most of the year. The eastern and central mountains have a rainfall in excess of 80 inches; the north coast has $50-75$ inches; but most of the south coast has only $25-45$ inches (Roberts and party, 1942).

\section{PREVIOUS WORK}

Puerto Rico has been under control of the United States since 1898 but few detailed geologic investigations have been made. Parts of the island were mapped on a reconnaissance scale by Berkey (1915, 1919), Semmes (1919), Hodge (1920), Lobeck (1922), Mitchell (1922), Hubbard (1923), Fettke (1924), and Meyerhoff (1931). Their work was published as part of the Scientific Survey of Porto Rico and the Virgin Islands. These reports served as the basis for Meyerhoff's "Geology of Puerto Rico", published for the nontechnical reader in 1933. Except for brief reports on various mineral deposits, little later geologic work was done until Zapp, Bergquist, and Thomas (1948) made a reconnaissance study of the Tertiary sedimentary 
rocks in 1944-1945. The ground-water resources of Puerto Rico are described in detail by McGuiness (1948). The most recent summary of the geology of the island is that by Mitchell (1954).

Excellent topographic maps of all parts of Puerto Rico have been made on scales of $1: 30,000$ and $1: 10,000$. The maps of smaller scale are now being revised. Aerial photos of the island taken in 1951, at an approximate scale of $1: 15,000$, are also available. A detailed soil survey on a scale of $1: 50,000$, Roberts (1942), serves as an excellent guide to the location of many of the rock types.

\section{ACKNOWLEDGEMENTS}

The writers wish to express their sincere appreciation to Dr. R: Fernandez Garcia, Director of the Industrial Laboratory of the Economic Development Administration of Puerto Rico, for his interest and assistance in the study. The members of the laboratory staff were also very helpful. Office space and laboratory facilities for U. S. Geological Survey personnel were furnished at the Industrial Laboratory in Hato Rey.

\section{SCOPE}

The reconnaissance survey of the beaches of Puerto Rico on which this report is based was made by the U. S. Geological Survey in cooperation with the Economic Development Administration of the Commonwealth of Puerto Rico, for the following reasons: (1) The large quantities of magnetite reported to occur in some of the beaches might be a potential source of iron ore, but the richest areas and the size of the deposits were not known, and (2) a study of the beach sands might indicate the locations of deposits of strategic minerals in parent rocks in the interior of the island. The coastline of the island was therefore investigated with special emphasis on the beach and dune sands occurring near the mouths of rivers. No attempt was made to include more than the unconsolidated sand deposits in this study, although some observations concerning the recently consolidated sands were made.

Field and laboratory work were done intermittently in 1953 and 1954.

\section{PROCEDURE}

Whenever possible, samples were taken from the tops and bottoms of walls of sand pits and dunes in order to determine the composition of the sand at depth. For the same reason, most surface samples represent a channel sample of the uppermost 1-3 feet of sand. Exceptionally rich layers were sampled to discover rare minerals, but these samples were not used in computing the general tenor of mag- 
netite. The samples were collected with a short-handle folding shovel.

A few exceptionally salty samples were washed, and then all samples were dried at $140^{\circ} \mathrm{F}$. Fractions of approximately 100 grams were mixed and then quartered down to smaller fractions from which samples of 20.0 grams were obtained. The magnetite was removed by spreading the sample into a layer approximately one-grain thick on a large, smooth sheet of paper and passing a hand magnet oneeighth to one-fourth inch above it. Grains lifted from the paper by the magnet were considered to be magnetite and were weighed.

The nonmagnetic portion of the sample was separated into two fractions having specific gravities either greater or less than 2.80 . This was done by using bromoform in a special separatory-funnel designed by C. S. Ross (1926) for the U. S. Geological Survey. The light nonmagnetic fraction, material floating on the bromoform and consisting of variable amounts of quartz, feldspar, and fragments of rock and shell, was weighed and briefly scanned under the binocular microscope. The heavy nonmagnetic fraction was also weighed, and the percentages by weight of both fractions were calculated. The nonmagnetic heavy minerals were then examined under a binocular microscope, at a magnification of 27 diameters, and separated into opaque and nonopaque groups of minerals. The nonopaque minerals were identified with the petrographic microscope by the oil-immersion method. Opaque minerals were determined by their physical properties, aided by qualitative chemical tests. Hematite, for example, is recognized by its characteristic color and streak; limonite appears, in these sands, nearly always as a pseudomorph after pyrite; ilmenite is recognized by its dull-black color and its weak magnetic susceptibility; and chromite by its occurrence as splendent black small octahedral crystals.

The percentage of each of the mineral constituents of the nonmagnetic heavy-mineral fractions was determined by grain count and computed as a component unit of the total percentage by weight of the heavy nonmagnetic fraction (tables 4 and 5). This was accomplished by thorough mixing, using a Jones microsplitter. A portion of the fraction, consisting of the number of grains that lay on the point of a small spatula, was then placed on a sorting-plate and the minerals were separated into mineral groups by hand with a pointed tool made of horn. Such work was lessened in a few cases by making a partial or even complete mineral separation with a Frantz electro-magnetic separator. 


\section{GENERAL GEOLOGY}

Puerto Rico is described by Meyerhoff (1933) as being underlain by a central east-west belt of Cretaceous rocks flanked on the north and south by Tertiary calcareous sedimentary rocks and by generally unconsolidated Quaternary sediments. The central east-west belt is mountainous, underlies two-thirds of the island, and consists of a complex of highly folded volcanic flows and pyroclastic rocks, shale, and limestone. Recent work by Hess, Slodowski, and Mattson (written communication) in the area south of Mayaguez and by Kaye (1956) southeast and southwest of the San Juan area indicates a Paleocene and possibly an Eocene age for some of the rocks heretofore considered to be Cretaceous in age. In its southwestern part the complex contains several bodies of serpentine, and in the central and eastern part, intrusions of granitic, andesitic, and dioritic rocks. Owens and Guillou (report in preparation) have obtained age determinations of 51-56 million years for rocks from the San Lorenzo batholith in southeast Puerto Rico. The serpentine and larger dioritic bodies are shown on plate 15. Meyerhoff (1955) states that at least 25 small exposures of intrusive rock, from one half to five square miles in area, are scattered throughout the mountains.

The younger Tertiary rocks, according to Zapp, Bergquist, and Thomas (1948), consist of clastic deposits in the basal part of the section and predominantly of limestone in the upper part, all lying unconformably on the Cretaceous and Early Tertiary rocks of the complex. These marine sedimentary rocks range in age from middle Oligocene to early Miocene.

The Quaternary sediments-alluvial deposits, consolidated and unconsolidated beach and dune sand, sandy limestone, silt, and claylie unconformably on the Cretaceous and early Tertiary rocks of the central complex and disconformably on the blanketing younger Tertiary strata. San Juan formation is the term that has been applied to various portions and types of the Quaternary sediments by Berkey, Mitchell, Lobeck, Hubbard, Meyerhoff, and other writers. We consider that until these deposits are studied in detail it is best to avoid using a formal stratigraphic term. Therefore, the sandstone and conglomerate of Quaternary age at or near sea level are referred to in this report as "consolidated sand" or "consolidated gravel". We believe that these deposits have accumulated during several recent periods of deposition and consolidation. 


\section{DESCRIPTION OF BEACHES}

The terminology adopted by Thompson (1937, p. 725), and McKee and Weir (1953, p. 381) will be used to describe the general features of the beaches of Puerto Rico. The upper foreshore, the part of the beach in front of its crest, is formed primarily by the action of waves and characteristically is stratified. The strata, which result from the sorting of minerals, range in thickness from a fraction of an inch to several inches. Cross-stratification is produced when the beach profile of equilibrium, which represents a balance between deposition and erosion, is disturbed as a result of variations in the quantity and type of material supplied by adjacent rivers, longshore currents, and organic life in the vicinity; in the tide level; in the slope of the shore; or by the interaction of these factors. As the shore of Puerto Rico is complex and continually changing, cross-stratification is common.

The sands of the beach crest and the backshore beach result from the action of winds and waves. During storms and times of unusually high tides, waves sweep over the crest and deposit sand on the backshore. When this sand has dried, the wind of ten winnows out the lighter grains to form small dunes and leaves a surface layer rich in heavy minerals. Backshore sands are a combination of sand-dune and storm deposits, and are therefore more complex than upper foreshore deposits.

The shores of Puerto Rico are classified on the basis of their character into swamp, rock outcrops, cobble beaches, and sand beaches. Swamps are limited to the southwest, south, and northeast shores of the island; and cobble beaches are restricted primarily to the south shore. Although bedrock outcrops and sand beaches occur on all shores, certain generalizations as to types of rock in different areas may be made.

Rocks of the central complex and younger sedimentary rocks form the outcrops of the east shore, except for a small area of recently consolidated sand and consolidated gravel at sea level in two small coves north of Punta Toro, and most of the outcrops of the northwest, west, and southwest shores of the island. Consolidated sand, which forms the rest of the outcrops on these shores is the principal rock exposed on the north shore from Luquillo to Camuy, and with consolidated gravel forms the only rock outcrops on the south shore from Ponce to Río Grande de Patillas, except for un extension of Eocene(?) limestone (Owens, J. P., written communication) of the central complex at central Aguirre.

In table 1 the nature of the coasts, the beaches, and the rocks of the source areas are briefly described. A more detailed description of the coasts and beaches for the reader who wishes further information concerning these features follows the table. 


\begin{tabular}{|c|c|c|c|c|c|c|c|c|}
\hline 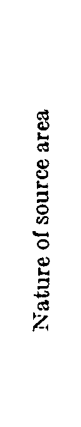 & 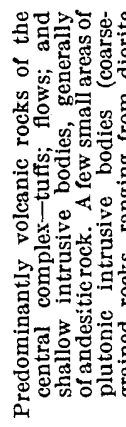 & 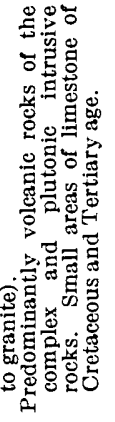 & 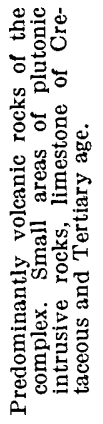 & 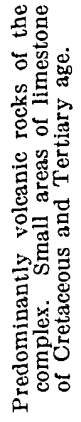 & 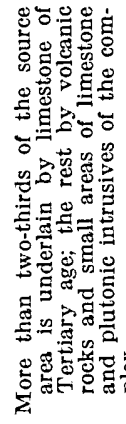 & 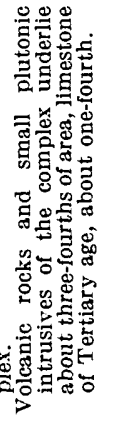 & 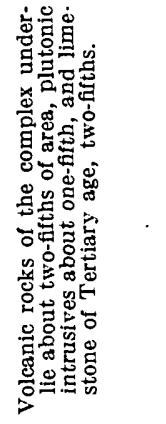 & 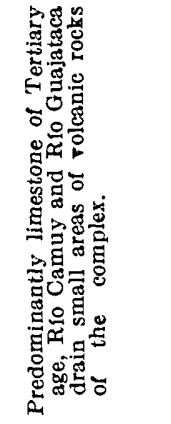 \\
\hline 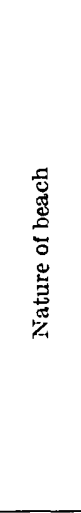 & 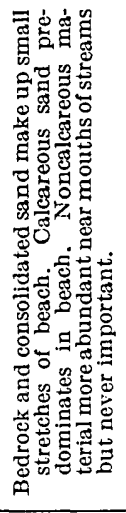 & 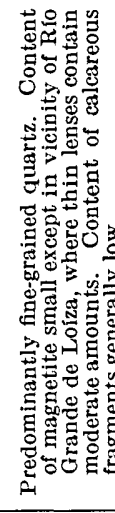 & 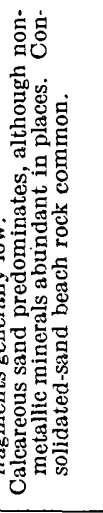 & 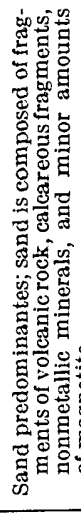 & 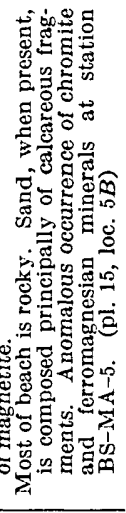 & 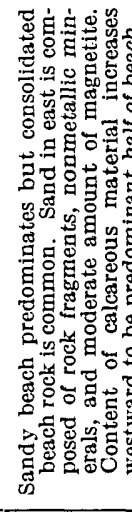 & 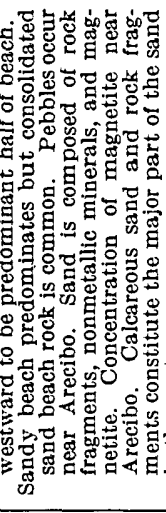 & 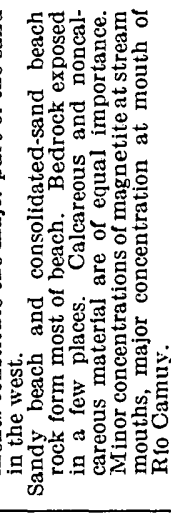 \\
\hline 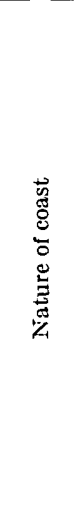 & 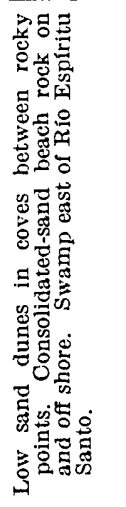 & 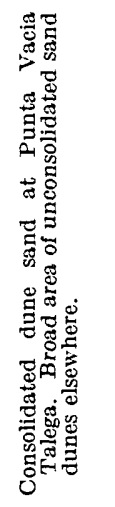 & 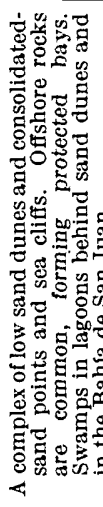 & 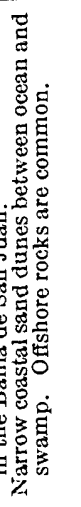 & 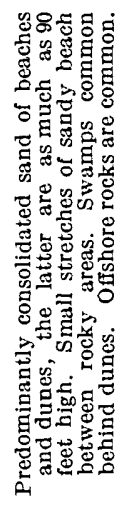 & 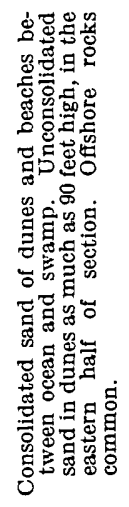 & 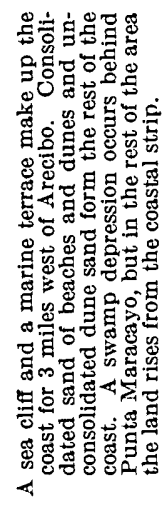 & 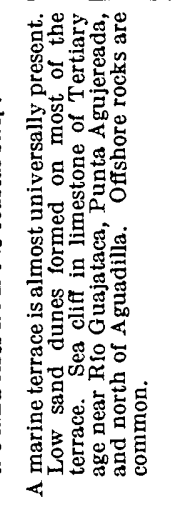 \\
\hline 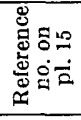 & $\rightarrow$ & $N$ & $\infty$ & + & $\infty$ & 0 & 1 & $\infty$ \\
\hline 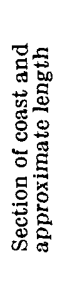 & 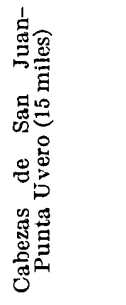 & 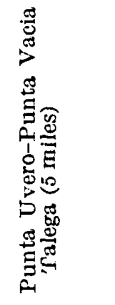 & 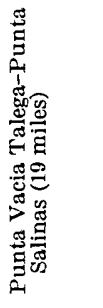 & 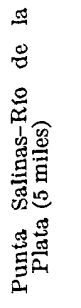 & 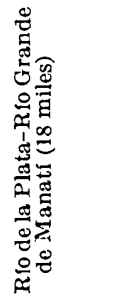 & 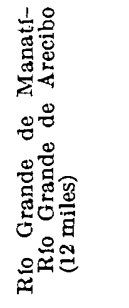 & 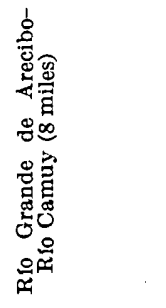 & 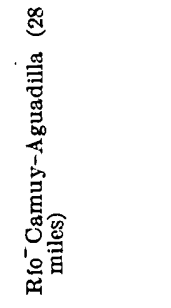 \\
\hline
\end{tabular}




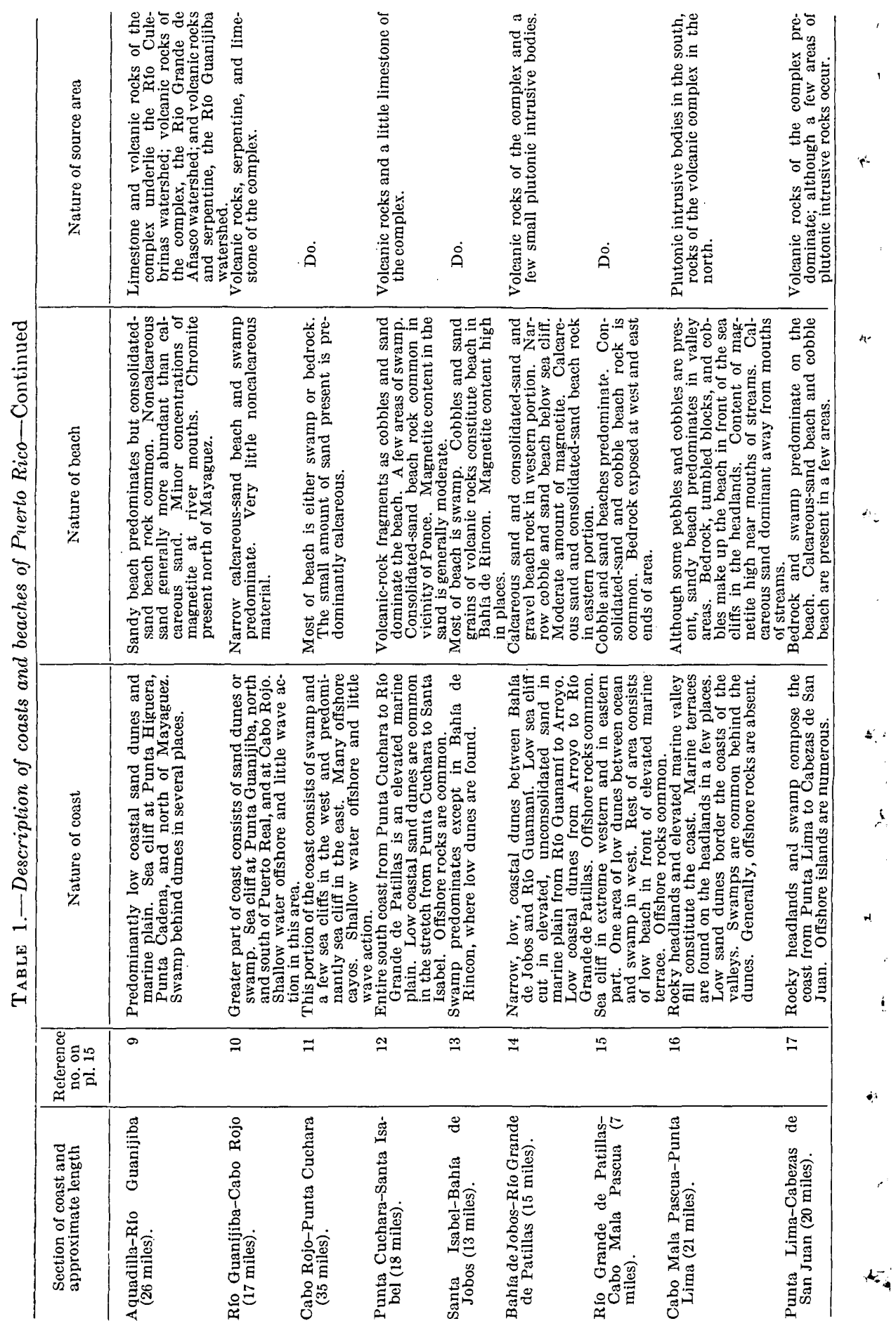


An explanation of the information depicted on plate 15 is believed necessary to prevent erroneous interpretation. Only a very generalized geologic map of Puerto Rico is presented to indicate the possible sources of beach sands. The reconnaissance mapping of Zapp, - Bergquist, and Thomas (1948) and the work of Roberts and others (1942) furnish the information for most of the map. Recent work by Hess, Mattson, and Slodowski (written communication) in the southwest portion of the island and by Owens and Guillou (in preparation) in the southeast corner result in more detail in these areas. Only a few areas of limestone and intrusive rock are differentiated in the central part of the island because of the lack of detailed mapping. These areas are not to be considered the only ones underlain by limestone and intrusive rock. Some of the contacts drawn between Quaternary deposits and older rocks were located by inspection of topographic maps and aerial photographs.

The character of the coast is indicated in a general way by combinations of four symbols representing rock outcrops, cobble beaches, sand beaches, and swamp. Sections of the coast described in table 1 and the text are indicated on plate 15 by figures. Localities sampled and other specific points referred to in the text are identified by letters.

\section{NORTH COAST}

The sands of the east and northeast coasts of Puerto Rico (pl. 15, secs. 1 and 17), from Naguabo almost to the mouth of the Río Grande de Loíza, contain small quantities of magnetite and other heavy minerals. Rocky points, mangrove swamps, and calcareous beaches constitute the shores of this section of the island, which is a coastline of submergence. The rivers draining the north and east flanks of the Sierra de Luquillo do not bring enough noncalcareous material to the beaches to be dominant over the calcareous sand derived from fragments of the multitude of organisms growing in the shallow coastal waters and from the erosion of consolidated calcareous sands.

From Punta Uvero, about 3 miles east of the mouth of Río Grande de Loíza, to Punta Vacia Talega, about 1 mile west of the river (pl. 15, sec. 1), the beaches contain less than 10 percent calcareous material and are predominantly fine-grained angular quartz. On aerial photographs, broad sweeping arcuate bands indicate sandy material as much as 1.5 miles inland.

Calcareous material predominates in the beaches from Punta Vacía Talega to the harbor of San Juan (pl. 15, sec. 2). A narrow beach, upon which the ocean waves break directly, extends for 4 miles between the ocean and lagoon from Punta Vacía Talega to Punta Maldonado. Punta Maldonado and the island of San Juan are composed of hard consolidated beach and dune sand, the sub- 
aerial remnants of coastal bars and dunes. Between these points submerged remnants of such features and the coral growing upon them, break the force of the waves so that the beaches are sheltered. From Cataño to Punta Palo Seco the beach is in the lee of the island of San Juan. The sands between Punta Palo Seco and Punta Salinas contain small quantities of magnetite.

A 200-foot-wide strip of coastal dunes, about 30 feet high, extends more than 3 miles west of Punta Salinas. The sand of the dunes contains a small quantity of magnetite. Behind this narrow strip of dunes is a low-lying reclaimed swampy area. Although the present mouth of the Río de la Plata is now to the west, the dunes undoubtedly are composed of material brought to the ocean by the Río de la Plata when its mouth was in the vicinity of Río Cocal.

The coast from Río de la Plata to Río Grande de Manatí, a distance of more than 18 miles, is predominantly rocky, being consolidated beach and dune sand, but small stretches of loose beach sand, for the most part calcareous, are present. Sands containing magnetite occur only on the banks of the Río de la Plata, in the small bay just west of it, and at one locality west of the Río Cibuco, where concentration of heavy minerals at station BS-MA-5 (pl. 15, loc. $5 B$ ) is anomalous, because it is the only concentration of heavy minerals that cannot be associated with a sizable stream course, and because it contains chromite of unexplained origin. This anomalous occurrence is probably due to transportation of the material by man, either as ballast in ships or during the construction of the nearby Army camp.

Sand deposits are found from the mouth of the Río Grande de Manatí to Punta Palmas Altas, a distance of 2 miles (fig. 31). Narrow dunes, as much as 90 feet high, extend west of the river mouth for more than 1 mile. A depression separates these barely stabilized dunes from the consolidated sands to the south. All five of the collection localities in the dunes yielded sand samples containing abundant heavy minerals. The sand in the walls of the pits was clean and appeared fairly uniform with the exception of vague crossstratification. The sand at different levels (table 3), however, varies considerably in the size of grains and in the content of magnetite.

Unconsolidated sand rich in magnetite rests on consolidated sand containing layers also rich in magnetite (figs. 31 and 32 ) in the cove, west of Palmas Altas (pl. 15, sec. 6). West of the cove are two 1-mile stretches of narrow coastal dunes, 30-60 feet high, rich in heavy minerals. Consolidated sand is found south of these deposits. 'The rest of the coast to Río Grande de Arecibo is composed of rocky promontories of consolidated sand and beaches of calcareous sand.

Sands rich in magnetite and other heavy minerals occur at the mouth of the Río Grande de Arecibo. The richest deposit is in 

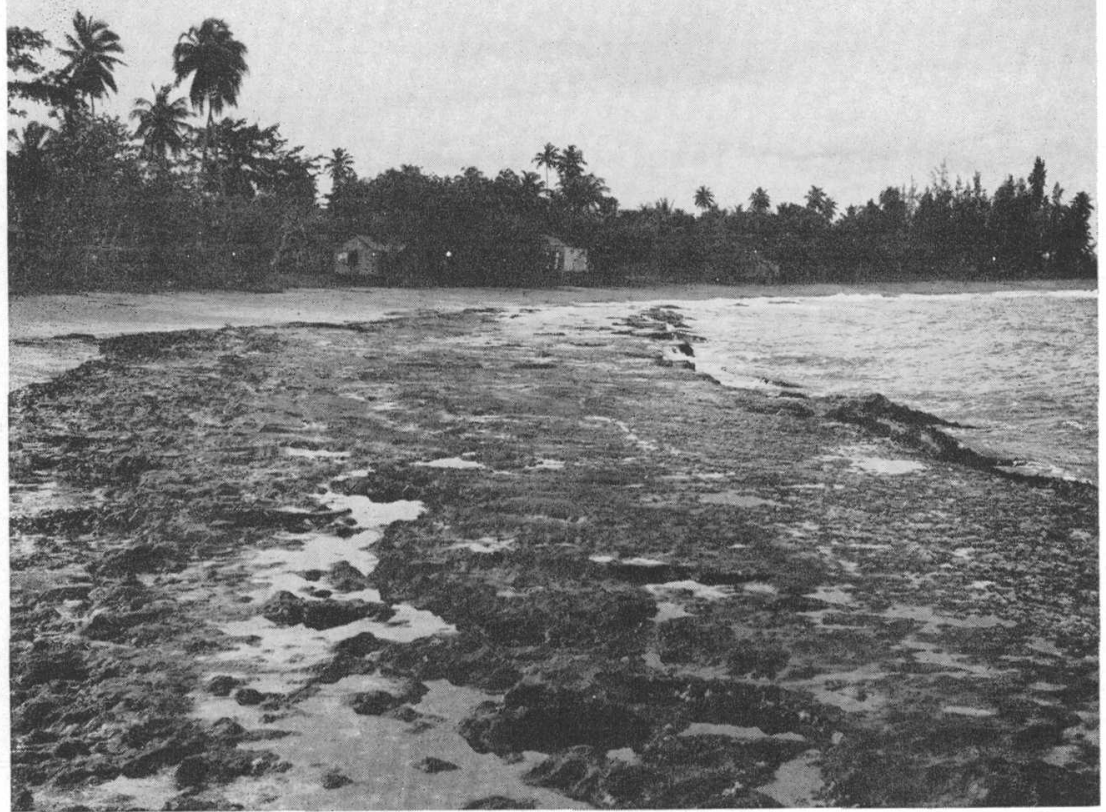

Figure 31.-View looking west from a point east of Palmas Altas, Puerto Rico.

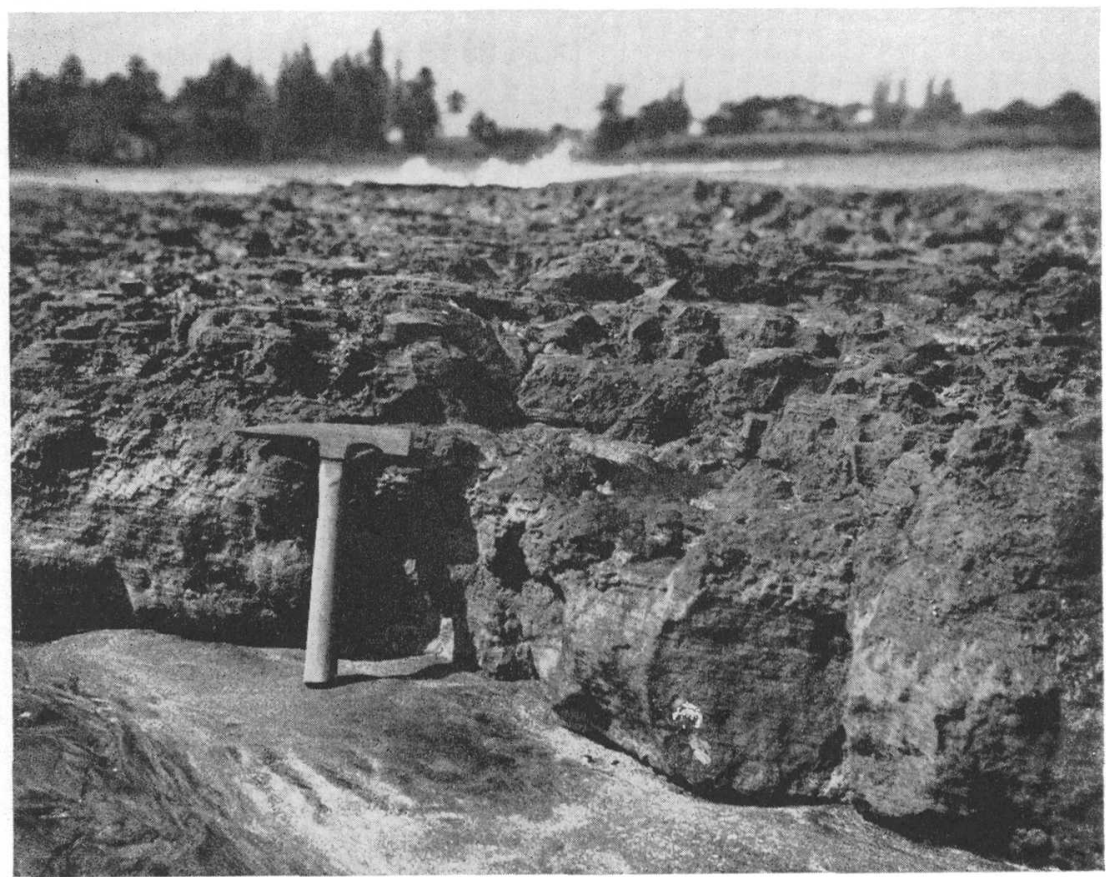

FIgURE 32.-Detail view of the banded magnetite-rich consolidated-sand beach rock on the north shore of Puerto Rico, west of Palmas Altas. 


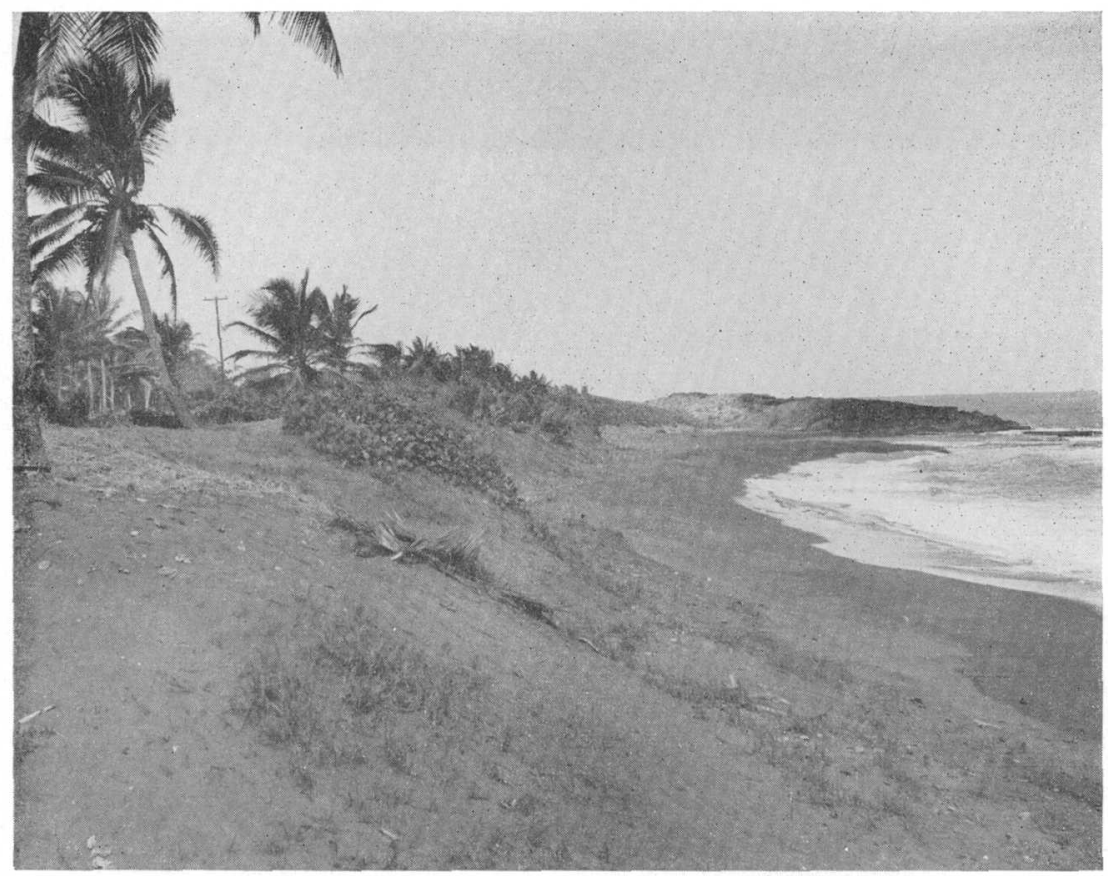

FIGURE 33.-View along the north shore of Puerto Rico, looking west from Palmas Altas.

Barrio La Marina, an island in the mouth of the river. The ocean has cut a sea cliff for 3 miles west of the mouth of the Río Grande de Arecibo and the area of beach is narrow and generally pebbly (pl. 15, sec. 7). Part of the city of Arecibo is built on sand dunes and on a pebbly terrace, 15 feet above sea level, which contains magnetite. The terrace extends 2.5 miles to the west and rises to a height of 45 feet. A sea cliff 3,000-feet long separates this terrace from a dune area to the west which contains abundant magnetite. The creek west of the sea cliff does not drain any areas underlain by Cretaceous and early Tertiary rocks and therefore the magnetite in the dune sand is either derived from the weathered Tertiary rocks of the area or it has been carried from the Río Grande de Arecibo by longshore currents. The latter explanation seems more probable.

From locality $7 B$ to Hatillo the beach consists of rocky areas composed of consolidated sand, and dunes as much as 30 feet high, which appear to be covering the rocky points.

A marine terrace 3.5 miles long and as much as one-half mile wide, and from 50 to 100 feet below the general level of the land to the south occurs near sea level at the mouth of the Río Camuy (pl. 15, sec. 7). A narrow coastal dune, 15-40 feet high and about 1,800 
feet long, and containing an appreciable quantity of magnetite lies to the east of the Río Camuy. West of the mouth of the river the dunes increase in height and width, and are 1 mile long, but the content of magnetite in the sand diminishes. West of Camuy for 1.5 miles, low dunes and consolidated sand form the rest of the shore.

A rocky coast extends from the point where the low terrace wedges out westward 5 miles to the Río Guajataca, with narrow terrace, just above sea level, separating the 100-150-foot-high limestone escarpment from the ocean.

A low, narrow, sandy terrace extends for 12 miles from the mouth of the Río Guajataca to the northwest tip of the island at Punta Agujereada. This terrace also lies between the ocean and the escarpment. At Punta Agujereada and at two places near the Río Guajataca, the escarpment meets the ocean to form sea cliffs. The sand of the terrace is composed of more than 50 percent noncalcareous material.

\section{WEST COAST}

The shore line from Punta Agujereada to Aguadilla consists of a sea cliff 1.5 miles long on the north, 2.5 miles of terrace, largely with consolidated-sand beach, and finally sea cliff for a distance of 2 miles on the south.

South of Aguadilla the Río Culebrinas flows into the ocean through the middle of a beach four miles long (pl. 15, sec. 8). A few small areas of consolidated sand occur at and below the level of high tide in this area. The quantity of magnetite and heavy minerals is small, although the sands in this stretch contain more than 50 percent noncalcareous material. A similar beach occurs for 3 miles between this beach and the rocks of Punta Higuero. Three small rivers cut the beach and surface concentrations of heavy minerals are found near their mouths.

Punta Higuero, the westernmost point of Puerto Rico, has three miles of rocky coast with very little sand. South of the point is a sandy beach about 3 miles long.

Sandy beaches and low, narrow, coastal dunes occur for about 2.5 miles on both sides of the mouth of the Río Grande de Añasco. The earlier channels of the river are evident in the form of caños, or long, narrow, land-locked sloughs almost at right angles to the coast. Concentrations of magnetite are found on the surface of the beach only in the immediate vicinity of the mouth of the river.

The sands of the beach bordering the Bahía de Mayaguez are dark, owing to the preponderance of sand grains derived from volcanic rock. 
The southwest and south coasts of Puerto Rico, from the Bahía de Mayaguez to the Bahía de Guayanilla (secs.10 and 11) have almost no noncarbonate beach deposits. Rocky points, mangrove swamps, and shell-fragment beaches predominate. No major streams bring sediments to the ocean and the materials supplied by the small intermittent streams are dissipated in the mangrove swamps or in the flood of carbonate material.

\section{SOUTH COAST}

Most of the Bahía de Guayanilla is rimmed with swamp or rock terraces cut in limestone of Tertiary age. The small areas of sand beach present contain only a negligible percentage of magnetite.

The sand grains in the beach of the Bahía de Tallaboa increase progressively in size from west to east. The littoral material changes from coarse sand composed of rock and shell fragments, on the small peninsula between the Bahía de Tallaboa and the Bahía de Guayanilla, to sand and cobbles in the vicinity of the mouth of the river entering the bay. No concentrations of magnetite were found on this beach.

The coast line from the Bahía de Tallaboa to Punta Cuchara consists of fine-grained detritus, swamp, and 2 miles of Tertiary-limestone sea cliff. Consolidated sand is locally present at the level of low tide.

The beach from Playa de Ponce to the Río Jacaguas (pl. 15, sec. 12) is predominantly sand composed of fragments of volcanic rocks, though the beach becomes more cobbly eastward. Consolidated sand occurs at the level of low tide and as offshore bars.

The coast from the mouth of the Río Jacaguas to Playa de Santa Isabel, a distance of more than 10 miles, is predominantly a cobbly beach, with magnetite-rich interstitial sand. At many places the cobbles are restricted to the strip between the levels of low and middle tide, the sand forming a layer 1-2 feet thick at, and above, the level of high tide. Very low dunes occur behind the beach in several areas.

Mangrove swamps and cobble beaches form the coast from Playa de Santa Isabel to the Bahía de Rincon (pl. 15, sec. 13). Cobbles, pebbles, and sand with abundant magnetite and other heavy minerals occur on the beach of the inner portion of the Bahía de Rincon. Arcuate remnants of sand dunes lie as much as 1,500 feet inland.

The coast from Salinas to Central Aguirre is predominantly a beach of carbonate sand and mangrove swamps. Except for the isolated rocks at Central Aguirre, the Bahía de Jobos is bordered by mangrove swamp. Calcareous sand, consolidated sand, and consolidated gravel constitute the arm of land separating the Bahía de Jobos from the Caribbean Sea. 
A very narrow beach of cobbles containing interstitial sand below a sea cliff cut in red-brown terrace material extends for 5 miles west from Arroyo. The sand contains abundant magnetite and other heavy minerals, which at several places are concentrated in layers as much as 3 inches thick. Three resistant areas of consolidated sand and gravels, and beaches composed of carbonate material, quartz, feldspar, and rock fragments, form the low coast from Arroyo to Patillas. The beach at the mouth of the Río Grande de Patillas consists of sand, gravel, and cobbles.

The coast from the mouth of the Río Grande de Patillas to the flood plain of the Río Maunabo (pl. 15, sec. 15), is a composite of rocky points and stretches of consolidated sand and consolidated gravel at the level of low tide and offshore. Carbonate sand occurs in sheltered areas, but sand, gravel, and cobble beaches occur at the mouths of small canyons.

\section{EAST COAST}

A low barrier dune less than 15 feet high has been built up across the flood plain of the Río Maunabo.

North of Punta Tuna (pl. 15, sec. 16), a coarse-grained granitic promontory, is a smooth beach predominantly of carbonate detritus. Pronounced terraces, $30-75$ feet above sea level, are present west of Punta Toro. The beach below the terraces is narrow and in many places cobbly. The beach at the mouths of the small ravines, and the beds of the ravines themselves, contain concentrations of magnetite that indicate the presence of considerable magnetite in the terraces. From Punta Toro to the Valle de Yabucoa, the granitic rocks of the Cuchilla de Panduras rise sharply from the Caribbean Sea, precluding large beach deposits.

A narrow, low, coastal dune, 6-8 feet high crosses the seaward end of the Valle de Yabucoa. Granitic materials are the chief constituents of the sand. The coast for 3 miles north of the Valle de Yabucoa is rocky except for narrow beaches in small coves.

Morro de Humacao, a granitic promontory 1,500 feet long, separates 2.5 miles of granitic and calcareous beach from the Humacao flood plain.

The 6 miles of sandy coast from the Río Humacao to the Río Santiago is interrupted only by El Morillo, a mass of volcanic rock 600 feet long which rises more than 100 feet above the low, sandy coastal plain. Surficial concentrations of magnetite are found on the beach near the mouths of the rivers in this area. Near the Río Humacao concentrations of magnetite are also found on storm terraces and on the surfaces of vegetation-covered 10-foot sand dunes. 


\section{SPECIAL FEATURES}

An outstanding feature of the north coast of Puerto Rico is the extensive development of recently consolidated "fossil dunes" and beach rock. These two distinct features were not separated in this reconnaissance survey. They occur irregularly from Luquillo on the east to Punta Agujereada on the west, from below sea level to more than 50 feet above sea level. Reefs or rocks are commonly present as en echelon lines at slight angles to the coast. At some localities sandstone displays characteristic eolian cross-stratification, but at others it appears to be of marine origin and fossils of corals, mollusks, and other invertebrates locally present substantiate the theory of marine deposition when the sea was higher in relation to the land than now. Nevertheless, the portions of the sands exhibiting eolian cross-stratification and the off-shore rocks require a lower sea level relative to the present strand during their deposition. The conditions for consolidation of the sand are still favorable in several places. West of Punta Palmas Altas, blocks of consolidated cross-stratified sand, which recently caved off the sea cliff, are now cemented together at the base of the cliff.

Consolidated sands and gravels are developed extensively on the west and south coasts, but they seldom occur more than a few feet above sea level. Coarse conglomerates are found at the mouths of some of the south-coast rivers. At sea level near Central Aguirre a dump of scrap iron has been converted into a conglomerate by iron-rich cement.

\section{DESCRIPTION OF SAND}

\section{TENOR OF MAGNETITE}

The tenor of magnetite in the beach sands of Puerto Rico is summarized in table 2, which shows the location, type, and extent of the various deposits and range in the content of magnetite. Estimated tonnage of magnetite and additional information concerning the deposits are included under Remarks.

\section{SIZE ANAL YSES}

Grain size analyses (figure 34) were made on samples of sand from ten localities and give a general idea of the character of the sand, the percent by weight of the size fractions, and the magnetite in each fraction.

Representative samples were analyzed from the rivermouth bars of the Río Grande de Arecibo, Río Grande de Loíza, Río Guayanés, Río Grande de Añasco, and Río Grande de Patillas. The coarse nature of sample BS-48 (pl. 15, loc. $16 D$ ) is attributed to the short length of the river and the coarse-grained dioritic source 
rock. Included in the 18 percent of material of +20 -mesh for this sample is less than 3 percent of material of +10 -mesh.

Data for GY-5 (loc. 14B) illustrate the distribution of size in the -10-mesh interstitial material from a typical cobbly beach on the south coast.

TABLE 2.-Tenor of magnetite in the beach sands of Puerto Rico

\begin{tabular}{|c|c|c|c|c|c|}
\hline \multicolumn{2}{|r|}{ Sample } & \multirow{2}{*}{ Type of deposit } & \multirow{2}{*}{$\begin{array}{l}\text { Length } \\
\text { (miles) }\end{array}$} & \multirow{2}{*}{$\begin{array}{l}\text { Magnet- } \\
\text { ite (per- } \\
\text { cent by } \\
\text { weight) }\end{array}$} & \multirow{2}{*}{ Remarks } \\
\hline $\begin{array}{l}\text { Location } \\
\text { on pl. } 15\end{array}$ & No. & & & & \\
\hline 2 & $\left\{\begin{array}{l}R G-2-R G-4 \\
C R-1\end{array}\right.$ & $\left\{\begin{array}{l}\text { Beach and broad area } \\
\text { of stabilized dunes. }\end{array}\right.$ & 3 & $0-2$ & \\
\hline $2 \Lambda$ & $\left\{\begin{array}{l}R G-1 \\
C R-5\end{array}\right.$ & \}Rivermouth beach.... & 1 & $2-5$ & $\begin{array}{l}\text { Small lenses contain more than } 10 \\
\text { percent of magnetite. }\end{array}$ \\
\hline $3 \mathrm{C}$ & $\left\{\begin{array}{l}\mathrm{BM}-3 \\
\mathrm{BM}-5\end{array}\right.$ & $\left\{\begin{array}{l}\text { Beach and low stabi- } \\
\text { lized dunes. }\end{array}\right.$ & 3 & $1-5$ & 1 \\
\hline 4 & $\left\{\begin{array}{l}B M-11-B M-15 \\
V A-1\end{array}\right.$ & $\begin{array}{l}\text { Beach and } 30-f 00 t \\
\text { dunes. }\end{array}$ & 3 & 5 & $\begin{array}{l}\text { Minimum estimate }-90,000 \text { tons } \\
\text { of magnetite. }\end{array}$ \\
\hline $6 \Lambda$ & $\mathrm{BC}-7-\mathrm{BC}-12$ & $\begin{array}{l}\text { Beach and 90-foot } \\
\text { dunes. }\end{array}$ & 1.5 & 10 & $\begin{array}{l}\text { Minimum estimate }-62,000 \text { tons } \\
\text { of magnetite. }\end{array}$ \\
\hline GC & $\left\{\begin{array}{l}B C-5 \\
B C-6\end{array}\right.$ & $\begin{array}{l}\text { Beach and } 60-\text { to } 90- \\
\text { foot dunes. }\end{array}$ & 2 & 5 & $\begin{array}{l}\text { Liberal estimate }-60,000 \text { tons of } \\
\text { magnetite. }\end{array}$ \\
\hline $7 \mathrm{~A}$ & A R-3-A R-9 & Rivermouth beach.: & 0.1 & $5-30$ & $\begin{array}{l}\text { Minimum estimate }-25,000 \text { tons } \\
\text { of magnetite. }\end{array}$ \\
\hline $7 \mathrm{~B}$ & CMI-3 & $\begin{array}{l}\text { Beach and 30-foot } \\
\text { dunes. }\end{array}$ & 0.1 & $10-30$ & 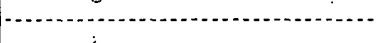 \\
\hline $8 \mathrm{~A}$ & $\left\{\begin{array}{l}C M[-7 \\
C M[-11 \\
A G-4-A G-7\end{array}\right.$ & $\left\{\begin{array}{l}\text { Beach and } 10-\text { to } 50 \text { - } \\
\text { foot dunes. }\end{array}\right.$ & 0.3 & 15 & $\begin{array}{l}\text { Minimum estimate--20,000 tons } \\
\text { of magnetite. }\end{array}$ \\
\hline 9 & $\left\{\begin{array}{l}\text { RI-1-RI-6 } \\
\text { MY-3-MY-6 }\end{array}\right.$ & Beach and low dunes. & 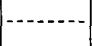 & $0-10$ & $\begin{array}{l}\text { Minor concentrations of magnetite } \\
\text { near mouths of rivers. }\end{array}$ \\
\hline $12 \AA$ & PC-1-PC-3 & $\begin{array}{l}\text { Narrow beach and } \\
\text { low dunes. }\end{array}$ & 1 & $5-10$ & - \\
\hline $12 \mathrm{C}-12 \mathrm{~F}$ & $\left\{\begin{array}{l}\text { PL-1-PI-4 } \\
\text { SI-1-SI-5 }\end{array}\right.$ & $\left\{\begin{array}{l}\text { Narrow beach and } \\
\text { low dunes. }\end{array}\right.$ & 11 & $5-30$ & $\begin{array}{l}\text { Magnetite abundant in interstitial } \\
\text { sand .of cobble beach. Possible } \\
\text { offshore deposits in shallow } \\
\text { water. }\end{array}$ \\
\hline $13 \mathrm{~A}$ & $\mathrm{SL}-1-\mathrm{SI}-15$ & Beach and low dunes. & 4 & $5-40$ & $\begin{array}{l}\text { Magnetite abundant in interstitial } \\
\text { sand of cobble beach and in sand } \\
\text { of low dunes. Possible offshore } \\
\text { deposits in shallow water. }\end{array}$ \\
\hline $14 . B$ & $\left\{\begin{array}{l}\text { GYY }-4 \\
G Y-5 \\
P^{r}-5\end{array}\right.$ & Narrow beach......... & 5 & $5-30$ & $\begin{array}{l}\text { Magnetite abundant in interstitial } \\
\text { sand of cobble beach. }\end{array}$ \\
\hline 16 & $\left\{\begin{array}{l}\mathrm{PC} \\
\mathrm{BS}\end{array}\right.$ & Beach and low dunes. & & $0-30$ & $\begin{array}{l}\text { Concentrations of magnetite near } \\
\text { river mouths. }\end{array}$ \\
\hline
\end{tabular}

Samples of dune sand from four localities were analyzed. The variation in distribution of grain size in the 30 -foot sand dune at locality $6 \mathrm{~A}$ is illustrated by size analyses of samples from near the top $(\mathrm{BC}-11 a)$, middle $(\mathrm{BC}-11 b)$, and base $(\mathrm{BC}-11 c)$ of the dune. The analyses of channel samples of the top (BM-12a) and bottom $(\mathrm{BM}-12 b) 5$ feet of a 10 -foot sea cliff in dune sand at locality $4 A$ yielded remarkably similar histograms.

These size analyses furnish data for only one valid generalization concerning the beach and dune sands of Puerto Rico. Magnetite always occurs as small grains. In every sample the magnetite was -40 mesh and in all but two analyses the magnetite of -60 mesh was equal to or greater in weight than the magnetite of +60 mesh.

Comparisons in content of magnetite between river-mouth sands and dune sands are not justified. Typical river-mouth sands were 
Vanadium-bearing magnetite-'Table 6 shows that magnetite from beach sands of 10 localities along the shore of Puerto Rico contains amounts of vanadium ranging from 0.24 to 0.44 percent.

Zircon-Zircon is a zirconium silicate $\left(\mathrm{ZrSiO}_{4}\right)$ that may contain small amounts of thorium, uranium, hafnium, and the elements of the rare earths. The zircon crystals in the Puerto Rico sands are colorless and usually about 1 millimeter long. Zircon occurs sparingly in most of the sands, but the samples indicate (table 6) that it is more abundant at Punta Puerto Nuevo (loc. $5 B$ ) and at Punta Guayanes. Zircon normally contains about 65 percent of $\mathrm{ZrO}_{2}$.

The demand for zircon was small in 1954. Australia has been the world's principal producer of zircon concentrates for many years; however, the Australian zircon producers are reported to be disturbed about the future markets for their zircon concentrates, because of (1) the potential competition of Brazil, Germany (Baltic Sea beach sands), French West Africa, and the Union of South Africa; and (2) the abundant output of the Florida operations which could produce more zircon if the demand warranted it.

\section{FREQUENCY DISTRIBUTION OF NONMAGNETIC HEAVY MINERALS}

Percentages of the magnetite-free heavy minerals listed in both tables 3 and 4 were determined by counting grains on a plate. A convenient sorting-plate is made from a piece of transparent glass, such as a lantern slide, to the back of which is cemented a piece of coordinate paper divided into squares 3 by 3 millimeters, or less.

Well-mixed fractions are used. Small amounts, 100-200 grains, are adequate. The mineral grains are arranged in a narrow thin row and are rapidly sorted by drawing the grains together with a microscope slide, or any small straightedge, and then drawing them out into a threadlike line. The dark minerals are now pushed to the right with a pointed nonmagnetic grain-separator and the light-colored minerals, to the left. The minerals of each species are then brought together to cover the 3 by 3 millimeter squares. The number of squares covered uniformly by each mineral is a measure of the total number of squares covered. Thus the relative proportions of different minerals may be determined. If grain sizes have been carefully considered, the percentages can be determined with a fair degree of accuracy.

This sorting-plate method was compared with the grain-counting method that uses the mechanical stage mounted on a microscope, and with the Chayes-point counter. Both these methods required more time than the sorting-plate method and show only minor variations in the proportions or percentages in the most abundant minerals.

Table 3 shows the varieties and the relative abundance of minerals that are found in 24 samples of beach sands collected from river 
mouths, dunes, and beaches around the Island of Puerto Rico. The combination of letters and figures in the left-hand column represent the reference numbers on plate 15 and the field identification numbers.

Direct percentages of the most common constituents in 13 samples of beach and dune sands from Puerto Rico are shown in table 4. These samples represent a fair average of the types of heavy minerals and the proportions of each in the beach and dune sands of Puerto Rico.

Column 3 shows the percentage of the "float", that is, the light fraction, composed of rock, shell, and minerals having a specific gravity of less than 2.8 .

Column 4 shows the percentages of magnetite, in samples which range from lean to moderately rich.

Column 5 shows the percentages of nonmagnetic heavy minerals. Epidote and pyroxene occur in about the same proportions and are the predominant minerals. Hornblende is next in abundance; ilmenite and sphene are persistent, but sphene never constitutes more than 3 percent of the heavy nonmagnetic minerals. These percentage ratios coincide with those shown in table 3 , but the use of percentages rather than symbols permits more detail to be shown.

\section{SPECTROGRAPHIC STUDY OF SAMPLES}

The primary objective of the spectrographic study was to discover any useful, rare or minor elements, especially niobium, that might occur in the black sands of Puerto Rico.

Of 24 samples of heavy minerals, from which magnetite had been removed, submitted for analysis, 16 were composite samples and 8 were samples of separated minerals. In the analyses (table 5) 24 elements are reported present and 17 others were looked for but not found. The column headed $\mathrm{Nb}$ gives the quantitative determination of niobium. Also examined spectroscopically (table 6) were 10 samples of magnetite. 


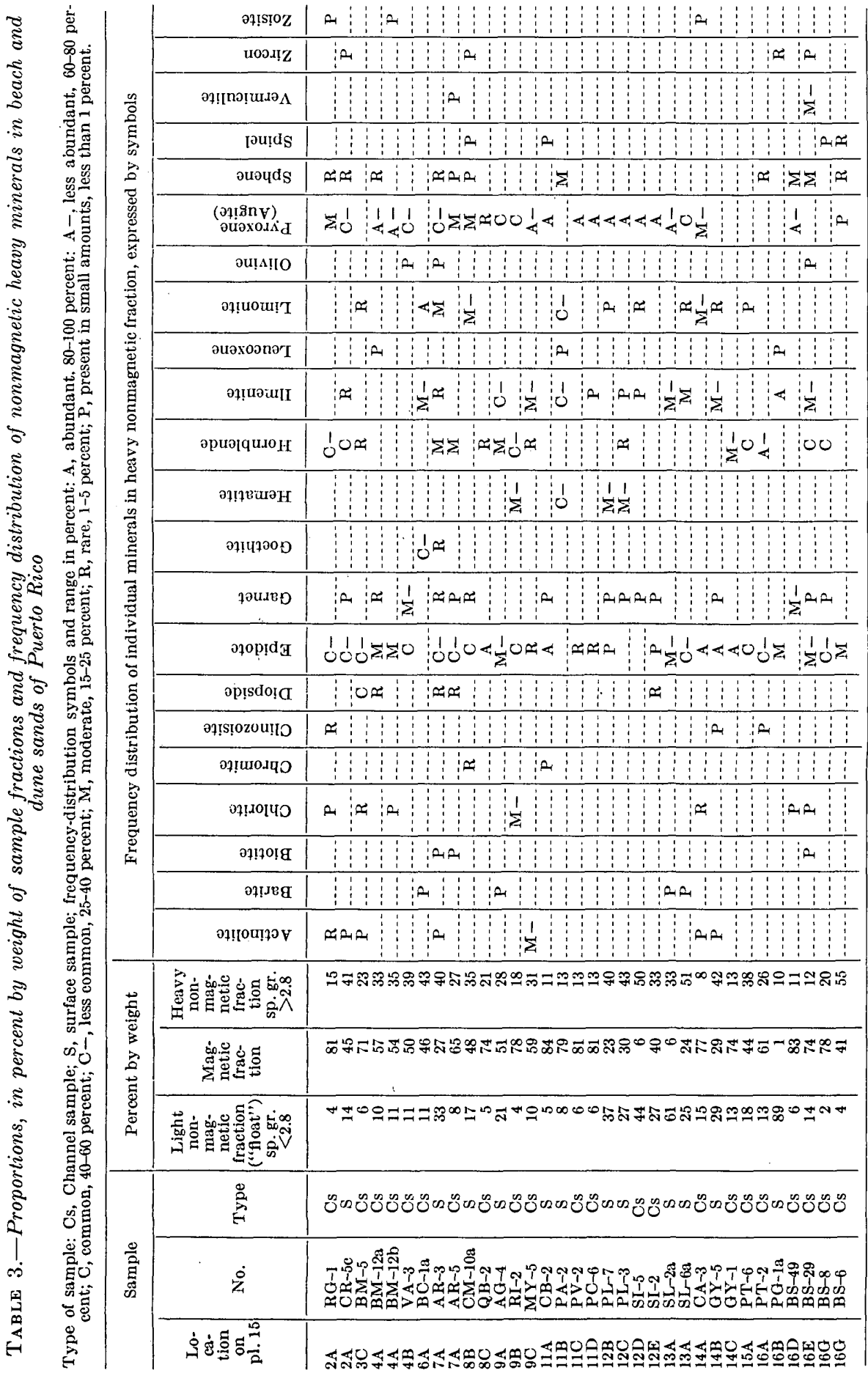




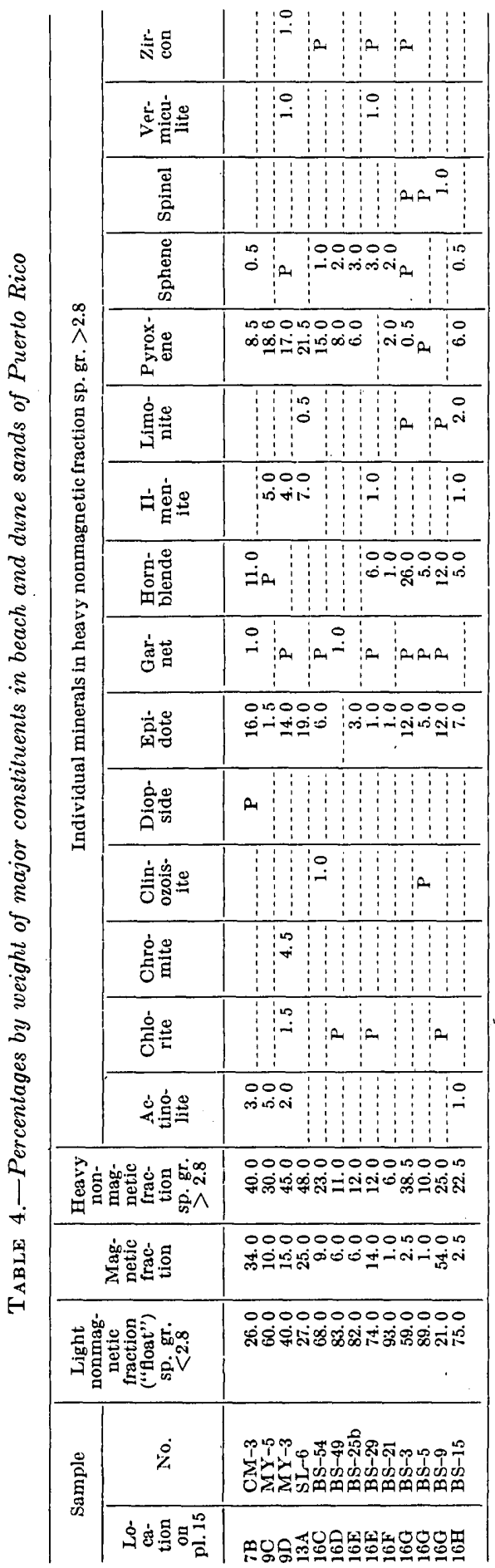




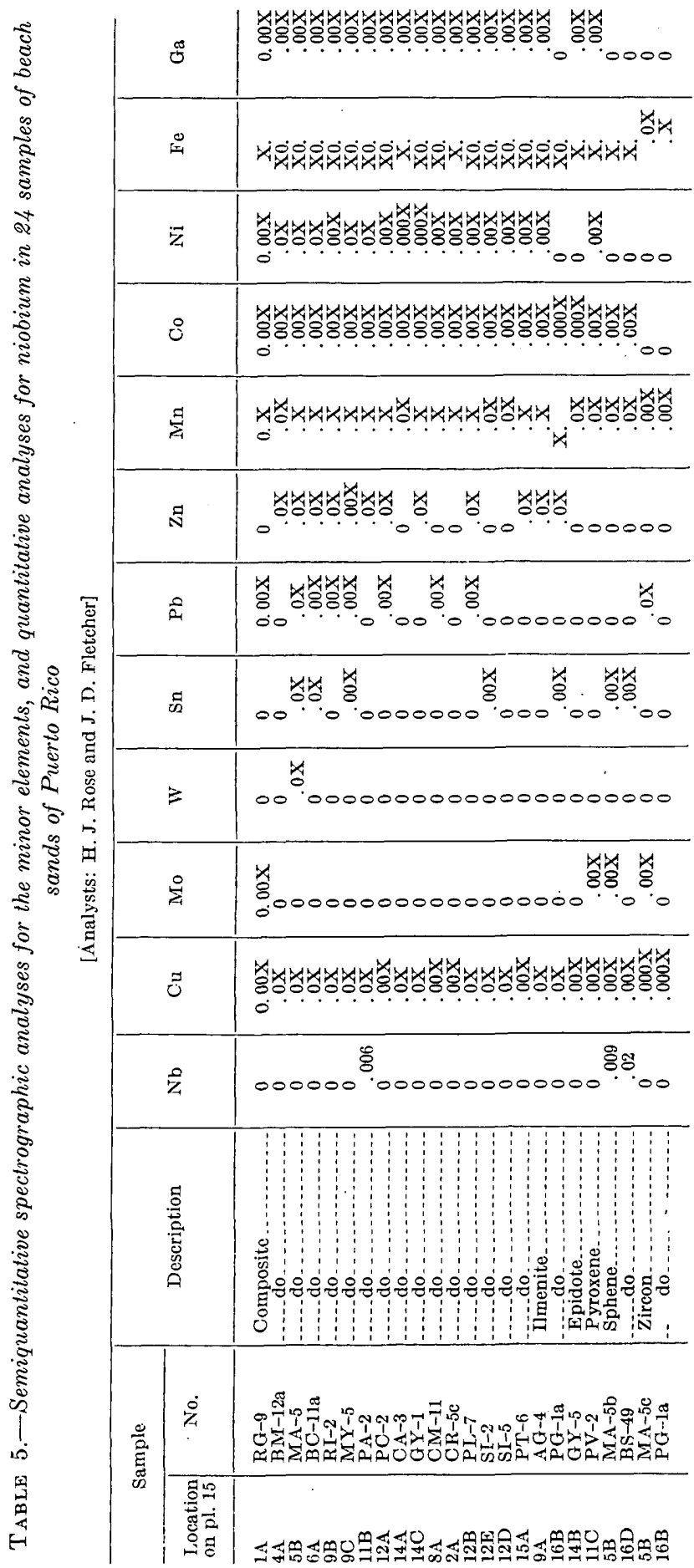




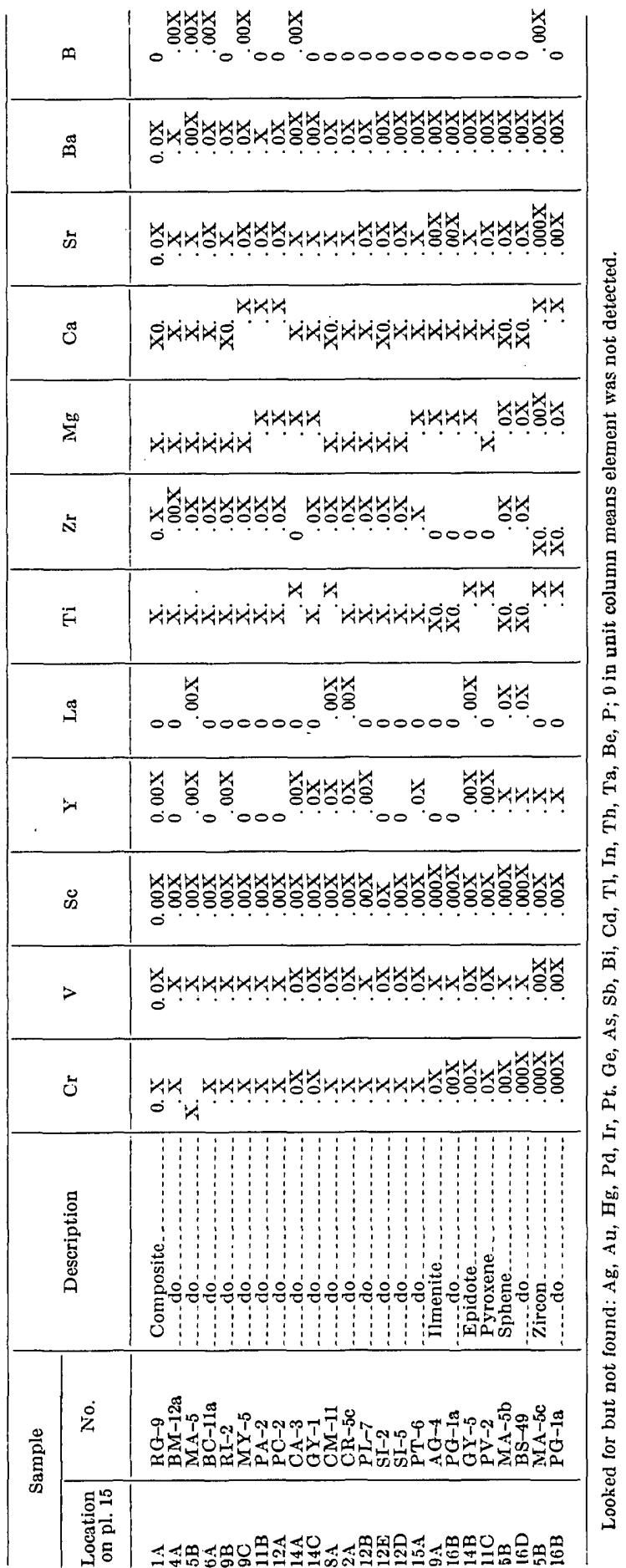


TABLE 6.-Semiquantitative spectrographic analysis for minor elements, ${ }^{1}$ and quantitative spectrographic analysis for vanadium in 10 samples of magnetite from beach sands of Puerto Rico.

[Analyst: J. D. Fletcher]

\begin{tabular}{|c|c|c|c|c|c|c|c|c|c|}
\hline $\begin{array}{l}\text { Loca- } \\
\text { tion on } \\
\text { pl. } 1\end{array}$ & Field no. & V & $\mathrm{Cu}$ & $\mathrm{Pb}$ & $\mathrm{Mn}$ & Co & $\mathrm{Ni}$ & Al & $\mathrm{Cr}$ \\
\hline $\begin{array}{l}7 \mathrm{~A} \ldots \\
6 \mathrm{~A} \ldots \\
4 \mathrm{~A} \ldots \\
8 \mathrm{~A} \\
2 \mathrm{~A} \\
9 \mathrm{C} \\
16 \mathrm{~B} \\
16 \mathrm{~B} \\
12 \mathrm{D} \\
16 \mathrm{E}\end{array}$ & $\begin{array}{l}\text { AR-3 } \\
\text { BC-11a.. } \\
\text { BM-12a.. } \\
\text { CM-11... } \\
\text { CR-5c } \\
\text { MY-5 } \\
\text { PG-2 } \\
\text { PG-1a. } \\
\text { SI-5 } \\
\text { BS-29... }\end{array}$ & $\begin{array}{l}0.42 \\
.28 \\
.33 \\
.32 \\
.24 \\
.35 \\
.31 \\
.33 \\
.41 \\
.28\end{array}$ & $\begin{array}{l}0.00 \mathrm{X} \\
.0 \mathrm{X} \\
.00 \mathrm{X} \\
.00 \mathrm{X} \\
.0 \mathrm{X} \\
.00 \mathrm{X} \\
.00 \mathrm{X} \\
.00 \mathrm{X} \\
.0 \mathrm{X} \\
.0 \mathrm{X}\end{array}$ & 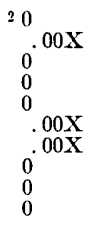 & $\begin{array}{l}0 . \mathrm{X} \\
. \mathrm{X} \\
. \mathrm{X} \\
. \mathrm{X} \\
. \mathrm{X} \\
. \mathrm{X} \\
. \mathrm{X} \\
. \mathrm{X}\end{array}$ & $\begin{array}{l}0.00 \mathrm{X} \\
.00 \mathrm{X} \\
.00 \mathrm{X} \\
.00 \mathrm{X} \\
.00 \mathrm{X} \\
.00 \mathrm{X} \\
.00 \mathrm{X} \\
.00 \mathrm{X} \\
.00 \mathrm{X} \\
.00 \mathrm{X}\end{array}$ & $\begin{array}{l}0.00 \mathrm{X} \\
.0 \mathrm{X} \\
.0 \mathrm{X} \\
.00 \mathrm{X} \\
.00 \mathrm{X} \\
.0 \mathrm{X} \\
.00 \mathrm{X} \\
.00 \mathrm{X} \\
.0 \mathrm{X} \\
.00 \mathrm{X}\end{array}$ & $\begin{array}{l}0 . \mathrm{X} \\
\mathrm{X} . \\
\mathrm{X} . \mathrm{X} \\
\mathrm{X} . \mathrm{X} \\
\mathrm{X} . \\
\mathrm{X} . \mathrm{X} \\
. \mathrm{X}\end{array}$ & $\begin{array}{l}0 . \mathrm{X} \\
. \mathrm{X} \\
. \mathrm{X} \\
. \mathrm{X} \\
. \mathrm{X} \\
.0 \mathrm{X} \\
. \mathrm{X} \\
.0 \mathrm{X}\end{array}$ \\
\hline $\begin{array}{l}\text { Loca- } \\
\text { tion on } \\
\text { pl. } 1\end{array}$ & Field no. & $\mathrm{Sc}$ & $\mathrm{Ti}$ & $\mathrm{Be}$ & $\mathrm{Ca}$ & $\mathrm{Sr}$ & $\mathrm{Ba}$ & $\mathrm{Mg}$ & Ga \\
\hline $\begin{array}{l}7 \mathrm{~A} \\
6 \mathrm{~A} \\
4 \mathrm{~A} \\
8 \mathrm{~A} \\
2 \mathrm{~A} \\
9 \mathrm{C} \\
16 \mathrm{~B} \\
16 \mathrm{~B} \\
12 \mathrm{D} \\
16 \mathrm{E}\end{array}$ & $\begin{array}{l}\text { AR-3 } \\
\text { BC-11a } \\
\text { BM-12a. } \\
\text { CM-11 } \\
\text { CR-5c- } \\
\text { MY } 5 \\
\text { PG-2 } \\
\text { PG-1a. } \\
\text { SI-5 } \\
\text { BS-29. }\end{array}$ & $\begin{array}{l}0 \\
.00 \mathrm{X} \\
.00 \mathrm{X} \\
0 \\
0 \\
.00 \mathrm{X} \\
.00 \mathrm{X} \\
0.00 \mathrm{X} \\
.0 .\end{array}$ & $\begin{array}{l}\mathrm{X} . \\
\mathrm{X} . \\
\mathrm{X} . \\
\mathrm{X} . \\
\mathrm{X} . \\
\mathrm{X} . \\
\mathrm{X} . \\
\mathrm{X} . \\
\mathrm{X} . \\
0 . \mathrm{x}\end{array}$ & $\begin{array}{l}0 \\
.000 \mathrm{X} \\
.000 \mathrm{X} \\
0 \\
0 \\
.000 \mathrm{X} \\
0 \\
0 \\
0 \\
0\end{array}$ & $\begin{array}{l}0 . \mathrm{x} \\
. \mathrm{X} \\
. \mathrm{X} \\
. \mathrm{X} \\
. \mathrm{X} \\
. \mathrm{X} \\
. \mathrm{x}\end{array}$ & $\begin{array}{l}0.000 \mathrm{x} \\
.000 \mathrm{X} \\
0^{0} \\
0 \\
.000 \mathrm{x} \\
0.000 \mathrm{x} \\
0^{.000 \mathrm{x}}\end{array}$ & $\begin{array}{l}0.000 \mathrm{X} \\
.0 \mathrm{X} \\
.0 \mathrm{X} \\
.000 \mathrm{x} \\
.000 \mathrm{X} \\
.0 \mathrm{X} \\
.0 \mathrm{X} \\
.000 \mathrm{x} \\
.0 \mathrm{X} \\
.000 \mathrm{x}\end{array}$ & $\begin{array}{l}0.0 \mathrm{X} \\
. \mathrm{X} \\
.0 \mathrm{x} \\
.0 \mathrm{x} \\
\mathrm{x} . \mathrm{x} \\
.0 \mathrm{X} \\
.0 \mathrm{X}\end{array}$ & $\begin{array}{l}0.00 \mathrm{X} \\
.00 \mathrm{X} \\
.00 \mathrm{X} \\
.00 \mathrm{X} \\
.00 \mathrm{X} \\
.00 \mathrm{X} \\
.00 \mathrm{X} \\
.00 \mathrm{X} \\
.00 \mathrm{X} \\
.00 \mathrm{X}\end{array}$ \\
\hline
\end{tabular}

1 Looked for but not found: $\mathrm{Ag}, \mathrm{Au}, \mathrm{Hg}, \mathrm{Bi}, \mathrm{Ir}, \mathrm{Pt}, \mathrm{Mo}, \mathrm{W}, \mathrm{Ge}, \mathrm{Sn}, \mathrm{As}, \mathrm{Sb}, \mathrm{Zn}, \mathrm{Cd}, \mathrm{Tl}, \mathrm{Y}, \mathrm{Yb}, \mathrm{La}, \mathrm{Zr}$, Th, Nb, Ta, U, P, B.

20 in unit column means element was not detected.

\section{COMPOSITE SAMPLAS (MAGNETITE-FREE)}

In order of abundance, the elements in the composite samples are: iron, calcium, titanium, magnesium, chromium, manganese, and vanadium. This may well have been predicted from tables 3 and 4 , which give data on the mineral composition of the black sands. Silicon is not reported because an equal weight of quartz was added to all of the samples to improve their arcing characteristics. Samples that show more than 10 percent calcium contain major amounts of epidote, pyroxene, and usually some sphene.

The amounts of niobium are too small to have economic importance, but the occurrence of niobium in these samples, always in sphene, is significant. The only composite sample (PA-2) which contained detectable amounts of niobium was unusually rich in sphene.

Chromium and vanadium occur in about the same proportions. Most of the chromium occurs in chromite, but magnetite contains tenths of a percent of the element and traces are found in other individual minerals. The unusually high content of chromium in composite sample MA-5 is due to its relative richness in chromite. Vanadium, in amounts of tenths of a percent, is common in mag- 
netite, hematite, ilmenite and sphene. Nickel in the composite sample is mostly attributable to its presence in magnetite. Cobalt, copper, and scandium are not sufficiently concentrated in any one mineral that any of them could serve as an index element for that mineral. Zirconium percentages are indicative of the amounts of zircon, although small amounts of zirconium may also be contributed by sphene. The sources of molybdenum, tungsten, tin, lead, zinc, yttrium and lanthanum are problematical.

Strontium, although not abundant, is reported in the analyses of all samples. No strontium-bearing mineral was detected in the heavy fractions, so the element undoubtedly is a component of calciumbearing minerals of the light fraction.

\section{MONOMINERALLIC SAMPIES}

Ilmenite-Spectrographic analysis indicates much more iron than titanium in sample AG-4, which suggests that the sample is an intergrowth of ilmenite and magnetite, a suggestion that receives some support from the presence of nickel. This sample from the extreme northwest coast of Puerto Rico also contains less manganese than does sample PG-1a from the southeast coast.

Much of the ilmenite is altered to a yellowish opaque material that may be leucoxene (in this instance, sphene). A trace of niobium confirms the presence of sphene. This alteration product can then account for some of the calcium in sample AG-4; however a small trace of calcium could be due to adhering particles of marine shells.

Epidote-One sample of epidote from Puerto Rico and two samples of epidote from different localities in Virginia (contributed by J. B. Mertie, U. S. Geological Survey) were analyzed under the same conditions. The results coincide with standard chemical analyses, with the addition of strong traces of titanium and strontium in the Puerto Rico sample and in one from Virginia, and faint traces of these elements in the other sample from Virginia. Faint traces of vanadium occur in all three samples.

Pyroxene-A sample of typical pyroxene-augite-shows weak traces of chromium, vanadium, and strontium, and strong traces of titanium.

Sphene-Table 6 shows the percentages of niobium found in two selected samples of sphene from different localities on the beaches of Puerto Rico. Besides niobium, the spectroscopic analyses show from one-tenth to one percent of yttrium.

Zircon-In addition to the normal constituents of zircon, titanium; calcium, iron, and yttrium are present in amounts up to one percent. 
Ten samples of magnetite from various localities along the beaches and from the coastal dunes of Puerto Rico were examined spectrographically, particularly for the vanadium content (table 6). The highest percentage of vanadium obtained is 0.42 and the lowest 0.24 , with an average of 0.33 for the ten samples. The percentages of vanadium were compared with results from a recent study of the magnetite deposits of the Adirondack Mountains of New York (personal communication from J. J. Fahey, U. S. Geological Survey). A series of seven samples showed variable amounts of vanadium, from 0.04 to 0.10 percent, with an average of 0.07 percent. Semiquantitative analyses were made for 15 other elements (table 7). Titanium is consistently high; all but one sample contains 1 percent or more titanium. Half of the samples contain 1 percent or more aluminum and the other half, 0.1-1 percent. Manganese and calcium occur in all samples to the extent of 0.1-1 percent; and chromium nearly the same. Magnesium is variable, $0.01-10$ percent. Other elements shown in table 7 occur in minor or negligible amounts.

\section{ECONOMIC GEOLOGY}

The heavy minerals described or elements obtained from them' when they occur in sufficient abundance, have several uses and are therefore economically important.

Chromium metal and its alloys are used in making stainless steel, chrome plating, and in high-speed and high-temperature steel. Chromite is used in the manufacture of chromium brick and refractory cement and in making chemicals used extensively in leather tanning. Chromium is a constituent in certain green, yellow, orange, and red pigments, and of similarly colored dyes.

The paint and ceramics industries consume most of the world's supply of ilmenite, using it in the form of titanium dioxide, an opaque white pigment. Titanium and its alloys, because of their strength, lightness, and resistance to heat and corrosion, offer particular advantages for civilian uses as well as for uses in military, marine, and aircraft equipment. Some ilmenite is also used as flux in the steel industry and as roofing granules.

Vanadium is used for its alloying properties, and for its grainrefining effect on steel. Much vanadium is used as ferrovanadium in the manufacture of tool steels and in high-strength structural steels. Vanadium oxide is used as a drier in paints, and as a catalyst in the glass and ceramics industry.

Zircon is used as a refractory and opacifier and is an important constituent of heat-resistant glass and porcelain. Metallic zirconium has many specialized uses in electrical and surgical equipment. 
In recent years considerable interest has been developed in the relative abundance of certain heavy minerals that occur in minor amounts in some beach sands. The rare earth metals and other rare elements found in these minerals are playing an important role as alloying elements in modern metallurgy. No significant amount of useful heavy minerals other than magnetite was indicated by this preliminary study of the black sands of the beaches of Puerto Rico. These sands yield small amounts of sphene and zircon, both of which contain small fractions of the rare-earth metals and other rare elements in addition to the important minor elements, titanjum in sphene, and zirconium in zircon. Other minor minerals are chromite and ilmenite. Chromite is present in several samples of concentrates, and ilmenite occurs in varying amounts associated with magnetite.

Heavy minerals other than magnetite are not sufficiently abundant in the Puerto Rico beach sands to have any present commercial value, but in consideration of the rapidly increasing uses of these minerals, even small, easily accessible deposits, and byproducts of magnetite-mining operations may yield some minor minerals in the future for local use.

Black sands are generally mined by power shovels or suction dredges. The heavy mincrals are recovered by gravity concentrators, such as the Humphrey Spiral or the concentrating-table. Batteries of concentrators are used in two large-scale operations in Florida. The heavy minerals, are then kiln-dried and are separated by electromagnetic and electrostatic machines, though gravity separators also are used.

The reconnaissance survey of the Puerto Rico beaches could not yield enough data for accurate estimates of the tonnage of magnetite present in the sand. The purpose of this survey was to determine those areas deserving further study. Figures on tonnage have been roughly estimated for those areas along the north coast where sampling in sea cliffs and sand pits provided three dimensional control. An accurate estimate of reserves in these areas could be made, based on information inexpensively obtained by hand auger or light-power equipment.

In the following estimates of tonnage, 1 percent of magnetite in a sample was assumed to indicate 1 pound of magnetite in each cubic foot of sand within limits of the deposits. This figure is conservative but moderately accurate for low percentages of magnetite.

Two channel samples in a narrow dune, at the mouth of the Río Camuy near Hatillo (pl. 15, loc. $8 A$ ), more than 1,800 feet long, contained 20 percent magnetite. On the basis of a very conservative estimate of 15 pounds of magnetite per cubic foot, this dune contains 20,000 tons of magnetite. 
Sand averaging more than 10 percent magnetite is found between the mouth of the Río Grande de Manatí and Punta Palmas Altas (pl. 15, loc. 6A). All samples collected in this belt of sand dunes, which extends for 6,000 feet, contain from 10 percent to more than 20 percent magnetite. Using the smaller figure, it is estimated this area of coastal sand would yield more than 62,000 tons of magnetite.

The several samples collected in Barrio La Marina, an island at the mouth of the Río Grande de Arecibo (pl. 15, loc. $7 A$ ), indicate that the sand of the island contains between 5 and 10 percent magnetite. Assuming 5 pounds of magnetite are in each cubic foot of sand, this would mean a deposit of 25,000 tons of magnetite

A narrow coastal dune area more than 3 miles long lies between the Río Cocal and the Río de la Plata (pl. 15, locs. 4A-4B). Samples of sand from this area indicate 90,000 tons of magnetite present, based on a 5 percent magnetite content.

These figures are believed to represent minimum tonnages of magnetite. A more optimistic but still conservative appraisal of the reconnaissance data would increase the Hatillo deposit by 25 percent to 27,000 tons, Punta Palmas Aitas by 25 percent to 78,000 tons, and La Marina by 50 percent to 37,000 tons. In addition, if two large areas of coastal dunes near Los Negritos (pl. 15, loc. 6C) are assumed to contain 5 pounds of magnetite per cubic foot of sand, they would contain 60,000 tons of magnetite. Magnetite-tonnage figures are tabulated below:

Area

Hatillo

La Boca.

La Marina

Río Cocal

Los Negritos

\begin{tabular}{rrr}
$\begin{array}{c}\text { Magnetite } \\
\text { (pounds } \\
\text { per cubic } \\
\text { foot })\end{array}$ & $\begin{array}{c}\text { Minimum } \\
\text { tonnage }\end{array}$ & \multicolumn{1}{c}{$\begin{array}{c}\text { Possible } \\
\text { tonnage }\end{array}$} \\
15 & 20,000 & 27,000 \\
10 & 62,000 & 78,000 \\
5 & 25,000 & 37,000 \\
5 & 90,000 & 90,000 \\
5 & $-\ldots, 000$ \\
& $-197,000$ & 292,000
\end{tabular}

No other large areas of magnetite-rich sand dunes are known on the island, but very rich beach sands and small dune areas occur at many places. If economic interest in the beach and dune sand develops, the lower flood plains of the large rivers on the north coast should be prospected for magnetite.

Abundant magnetite is found on the south coast from Ponce to Patillas. Most of this magnetite occurs in beach sand and in the sand between cobbles, rather than in dune sand. Offshore sampling was attempted in one locality on the south coast and revealed a 10percent content of magnetite for the sand of the sea floor 300 feet from shore in ten feet of water. Although the visible deposits on 
the south coast are small, when the length of the beaches and the width of the shallow water zone are considered, this area may warrant further study.

\section{LITERATURE CITED}

Berkey, C. P., 1915, Geological Reconnaissance of Porto Rico: New York Acad. Sci. Annals, v. 26, p. 1-70.

1919, Introduction to the geology of Porto Rico: New York Acad. Sci., Scientific Survey of Porto Rico and the Virgin Islands, v. 1, pt. 1, p. 11-29.

Fettke, C. P., 1924, The Geology of the Humacao District, Porto Rico: New York Acad. Sci., Scientific Survey of Porto Rico and the Virgin Islands, v. 2, pt. 2, p. 117-197.

Hodge, E. T., 1920, The Geology of the Coamo-Guayama District, Porto Rico: New York Acad. Sci., Scientific Survey of Porto Rico and the Virgin Islands, v. 1, pt. 2, p. 111-228.

Hubbard, B., 1923, The Geology of the Lares District, Porto Rico: New York Acad. Sci., Scientific Survey of Porto Rico and the Virgin Islands, v. 2, pt. 1, p. 1-115.

Kaye, C. A., 1956, Lower Tertiary of Puerto Rico: Am. Assoc. Petroleum Geologists Bull., v. 40, p. 108-121.

Lobeck, A. K., 1922, The Physiography of Porto Rico: New York Acad. Sci., Scientific Survey of Porto Rico and the Virgin Islands, v. 1, pt. 4, p. 301-379.

McKee, E. D., and Weir, G. W., 1953, Terminology for stratification and crossstratification in sedimentary rocks: Geol. Soc. America Bull., v. 64, no. 4, p. 381-390.

Meyerhoff, H. A., 1931, The Geology of the Fajardo District, Porto Rico: New York Acad. Sci., Scientific Survey of Porto Rico and the Virgin Islands, v. 2, pt. 3, p. 201-360.

-_ 1933, Geology of Puerto Rico: Puerto Rico Univ. Mon., Ser. B, no. 1, p. 306.

McGuinness, C. L., 1948, Ground water resources of Puerto Rico: Puerto Rico Aqueduct and Sewer Service, San Juan, Puerto Rico.

Mitchell, G. J., 1922, The Geology of the Ponce District, Porto Rico: New York Acad. Sci., Scientific Survey of Porto Rico and the Virgin Islands, v. 1, pt. 3, p. 229-300.

Mitchell, R. C., 1954, A survey of the geology of Puerto Rico: Puerto Rico Univ. Tech. Paper B.

Roberts, R. C., 1942, Soil Survey, Puerto Rico: U. S. Dept. of Agr., Bur. Plant Industry Soil Survey Report, Series 1936, no. 8, p. 1-503.

Ross, C. S., 1926, Methods of preparation of sedimentary materials for study: Econ. Geology, v. 21, p. 454-468.

Semmes, D. R., 1919, The Geology of the San Juan District, Porto Rico: New York Acad. Sci., Scientific Survey of Porto Rico and the Virgin Islands, v. 1, pt. 1, p. 33-1.10.

Thompson, W. O., 1937, Original structures of beaches, bars, and dunes: Geol. Soc. America Bull., v. 48, p. 723-752.

Zapp, A. D., Bergquist, H. R., and Thomas, C. R., 1948, Tertiary Geology of the coastal plains of Puerto Rico: U. S. Geol. Surv. Oil and Gas Inc. Prelim. Map 85. 



\section{INDEX}

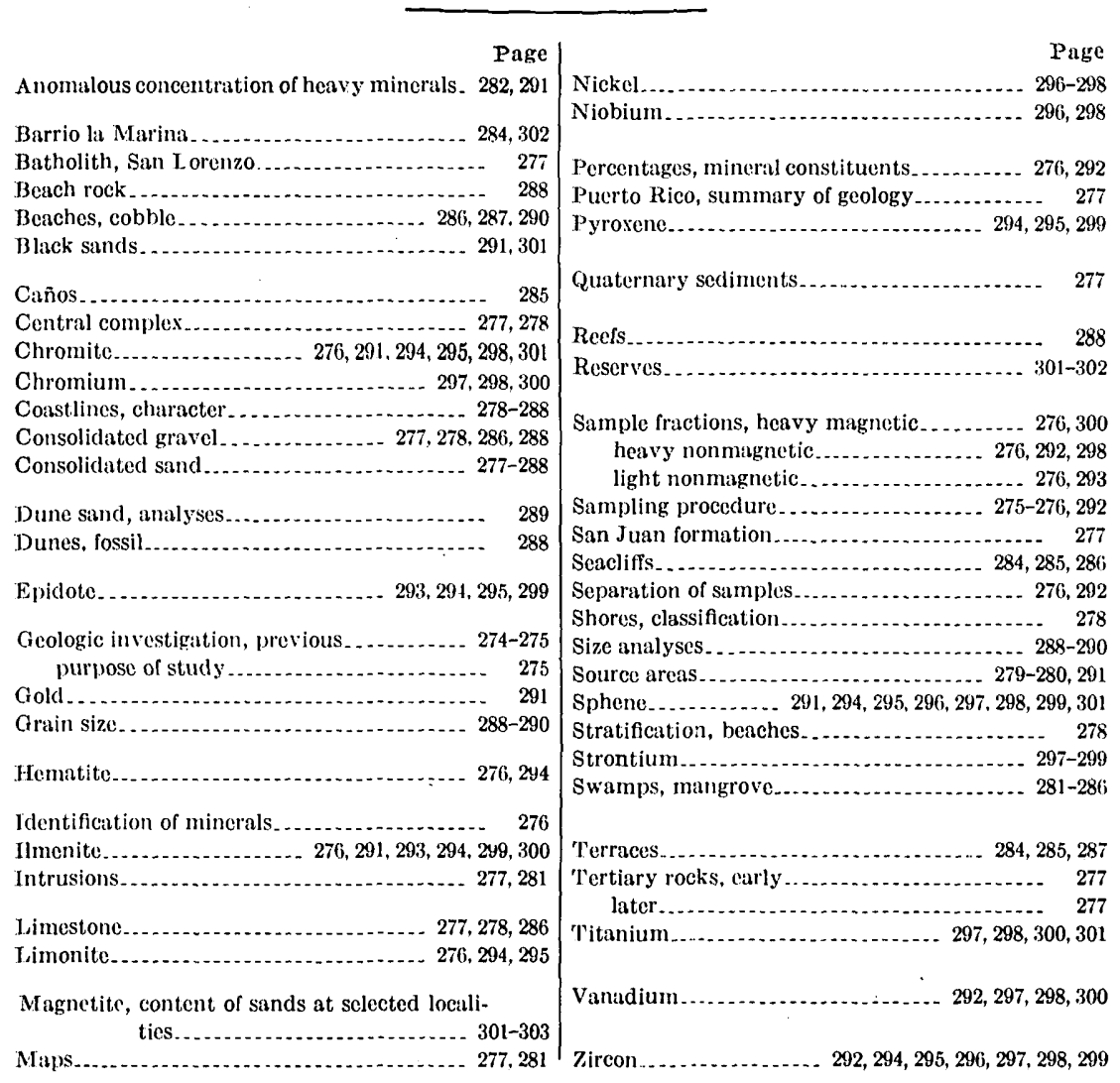

